\title{
Analisis dan Desain Software Jejaring Kata untuk Menghitung Kemiripan antar Kata Menggunakan Graph Database
}

\author{
Muhammad Rizal Musthofa ${ }^{1, *}$, Bintang Miftaqul Huda², Muhammad Zaim Maulana ${ }^{3}$, Muhammad \\ Ainul Yaqin ${ }^{4}$ \\ Jurusan Teknik Informatika, Universitas Islam Negeri Maulana Malik Ibrahim, Indonesia \\ ${ }^{1} 15650048 @$ student.uin-malang.ac.id; ${ }^{2} 19650093 @$ student.uin-malang.ac.id; ${ }^{3} 19650058 @$ @tudent.uin-malang.ac.id; \\ ${ }^{4}$ yaqinov@ti.uin-malang.ac.id \\ * corresponding author
}

INFO ARTIKEL

Sejarah Artikel

Diterima: 29 Mei 2021

Direvisi: 18 Juni 2021

Diterbitkan: 30 Agustus 2021

Kata Kunci

Jejaring kata

Graph database

Metode Path Similarity

Waterfall Model

\section{ABSTRAK}

Jejaring kata atau wordnet merupakan representasi hubungan semantik berupa sinonim antar kata. Saat ini penelitian terkait wordnet berbahasa Indonesia masih begitu minim. Adapun wordnet berbahasa Indonesia yang ada, belum menggunakan graph database sehingga belum bisa menampilkan kemiripan antar kata secara visual. Oleh karena itu, masalah yang dirumuskan pada penelitian ini yaitu cara menentukan tingkat kemiripan antar kata dalam jejaring kata berbahasa indonesia. Penelitian ini bertujuan untuk mendesain software wordnet berbahasa Indonesia untuk menentukan tingkat kemiripan antar kata berbahasa Indonesia. Dengan wordnet ini akan memudahkan proses pencarian nilai similaritas pada suatu kata. Metode yang ada dalam pengembangan aplikasi wordnet menggunakan metode waterfall model yang terdiri dari beberapa tahap requirement, desain, implementasi, verifikasi, dan maintenance. Aplikasi ini terdiri atas struktur dataset kata berbahasa Indonesia berbentuk graph database Neo4J yang digunakan dalam pencarian kemiripan antar dua kata. Proses pencarian nilai similaritas dalam aplikasi ini menggunakan metode path similarity sehingga diperolah nilai kemiripan dari dua kata yang diinputkan ke dalam sistem. Adapun penelitian ini hanya menggunakan dataset kata berbahasa Indonesia dan memiliki jumlah dataset yang masih terbatas. Penelitian ini berkontribusi dalam pengembangan software jejaring kata berbahasa Indonesia menggunakan graph database. Hasil penelitian yang didapat berupa desain software jejaring kata untuk menghitung kamiripan kata menggunakan graph database. Dengan adanya pengembangan software tersebut, mampu menyelesaikan permasalahan seputar perhitungan kemiripan kata.

\section{PENDAHULUAN}

Jejaring kata adalah sebuah database leksikal yang memiliki hubungan semantik dengan menggolongkan kata kerja (verb), kata keterangan (adverb), kata sifat (adjective), dan kata benda (noun) menjadi set sinonim yang dikenal dengan istilah synset. Hubungan semantik ini berfungsi untuk mengatur basis pengetahuan leksikal dari mulai dari hipernim sampai sinonim kata. Set sinonim kata (synset) diatur menjadi suatu indra, memberikan sinonim dari setiap kata, dan juga menyediakan struktur seperti pohon hirarki untuk masing-masing istilah [1].

Wordnet atau jejaring kata dalam Bahasa Indonesia pada saat ini yakni sinonimkata.com. Wordnet sinonimkata.com merepresentasikan hubungan semantik berupa sinonim antar kata. Sinonimkata.com merupakan kamus tesaurus yang menyediakan dataset Bahasa Indonesia 
yang bisa dipergunakan dalam pencarian kemiripan kata [2]. Wordnet sinonimkata.com direpresentasikan dalam bentuk graph.

Salah satu metode penyimpanan data kata dalam wordnet yakni dengan menggunakan graph database. Graph database merupakan penyimpanan data berbentuk diagram atau grafik yang struktur datanya terdiri dari edge dan vertices. Graf sendiri adalah pasangan terurut $\mathrm{G}=(\mathrm{V}, \mathrm{E})$ yang tersusun dari himpunan $\mathrm{V}$ atau simpul bersama-sama dengan set $\mathrm{E}$ tepi atau garis [3]. Graph database digunakan untuk mencari keterkaitan antar kata dalam suatu jejaring kata dengan cara megukur panjang jalur antara satu kata dengan kata yang lain. Penggunaan graph database lebih dinamis dan mampu mengetahui secara visual bentuk sinonim kata. Kelebihan model graf dalam representasi hubungan antar objek atau node mulai diadopsi ke dalam basis data. Selain itu graph database sangat baik untuk pengelolaan basis data yang tidak terstruktur. Query dari graph database lebih sederhana. Representasi dari graph database dengan sekala besar, diambil sinonim yang menghasilkan graph yang lebih spesifik atau skala kecil [4]. Graph database lebih dinamis, hal itu disebabkan karena pada relational database akan membutuhkan query yang lebih kompleks, sehingga ketika akan direlasikan, perlu query satu persatu. Karakteristik graph database ini sesuai dengan karakteristik dataset kata pada jejaring kata yang kompleks, sehingga lebih mudah untuk diimplementasikan untuk membangun software jejaring kata [5]. Pada penelitian ini, digunakan Neo4j untuk membantu menyimpan dataset dalam bentuk graph.

Adapun fakta penelitian terkait wordnet yang telah dilakukan peneliti sebelumnya, membahas mengenai hubungan semantik pada WordNet. WordNet pada penelitian tersebut merupakan software jejaring kata Bahasa Inggris yang didesain oleh Universitas Princeton [6]. Pada penelitian sebelumnya juga, peneliti ada yang membahas mengenai pegukuran kemiripan makna antar kalimat. Pada penelitian tersebut, pengukuran kemiripan menggunakan software WS4J dengan pendekatan lin, wu palmer, dan path [7]. Terdapat juga penelitian yang membahas mengenai pengukuran kemiripan makna kalimat berbahasa Indonesia [2]. Pada penelitian tersebut, kalimat yang digunakan berbahasa Indonesia. Namun hasil penelitian tersebut belum mengimplementasikan graph database Neo4J ke dalam bentuk software.

Dari fakta penelitian diatas, menunjukkan bahwa rata-rata software jejaring kata yang ada saat ini adalah wordnet berbahasa Inggris. Adapun software jejaring kata untuk menghitung kemiripan kata menggunakan graph database berbahasa Indonesia masih minim dikembangkan oleh peneliti. Hal ini dibuktikan dari adanya beberapa software jejaring kata berbahasa Inggris seperti WS4J (https://ws4jdemo.appspot.com/) dan WordNet Princenton (http://wordnetweb.princeton.edu). Kemudian dibuktikan juga software jejaring kata berbahasa Indonesia seperti WordNet Indonesia dan WordNet Bahasa Indonesia berbasis Linked Data [8][9].

Oleh karena itu, masalah yang dirumuskan pada penelitian ini yaitu bagaimana menentukan tingkat kemiripan antar kata dalam jejaring kata berbahasa Indonesia berdasarkan desain software yang dibuat. Untuk menentukan kemiripan antar kata pada jejaring kata diperlukan struktur data dan algoritma perhitungan kemiripan kata yang sesuai. Berdasarkan hal tersebut, digunakanlah graph database untuk mencari keterkaitan kata dalam jejaring kata dan mendapatkan panjang jalur setiap node nya. Panjang jalur yang dihasilkan akan menjadi komponen penting dalam perhitungan kemiripan kata. Penelitian ini ditujukan untuk mendesain dan menganalisis software jejaring kata untuk menghitung kemiripan kata menggunakan graph database. Software ini harapannya akan berguna untuk membantu menentukan tingkat kemiripan antar kata berbahasa Indonesia. 


\section{METODE}

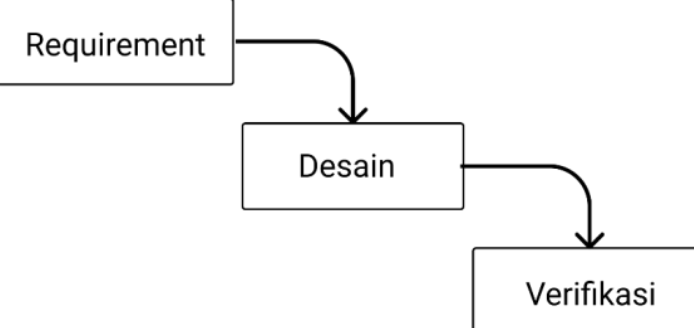

Gambar 1. Prosedur penelitian

Gambar 1 menunjukkan proses pengembangan suatu sistem perangkat lunak menggunakan model waterfall. Model tersebut menyediakan ancangan dari alur pengembangan perangkat lunak dalam konteks sekuensial (sequential linear). Alur pengembangan pada penelitian ini terurut mulai dari requirement, desain, sampai verifikasi desain perangkat lunak [10].

\section{Data Penelitian}

Data penelitian berasal dari data primer (data awal) dan data sekunder. Data primer (data awal) yang digunakan dalam penelitian berasal dari sinonimkata.com. Sedangkan data sekunder menggunakan metode path sebagai metode untuk meyelesaikan permasalahan penelitian.

\section{Analisis Requirement}

Pada saat mendeskripsikan suatu sistem terasa sulit jika tanpa sebuah analisis kebutuhan software. Hal ini bisa saja mengakibatkan kebutuhan sistem yang dibuat tidak bisa menyelesaikan permasalahan. Oleh karena itu, diperlukan suatu analisis requirement supaya dapat dipahami perangkat lunak atau software seperti apa yang diperlukan oleh pengguna. Analisis kebutuhan software digunakan untuk mengungkapkan keperluan dan batasan yang ada pada produk perangkat lunak atau software yang berkontribusi pada pemecahan beberapa masalah dunia nyata [11]. Analisis kebutuhan dibagi atas dua hal, yakni kebutuhan nonfungsional, dan kebutuhan fungsional.

\section{Fungsional Requirement}

Fungsional requirement adalah suatu keperluan bagaimana suatu sistem memproses input dan output. Fungsional requirement menggambarkaan fungsi yang dijalankan oleh perangkat lunak. Fungsional requirement sebagai salah satu rangkaian uji coba terbatas untuk menvalidasi perilaku sebuah software [11].

\section{Non-fungsional Requirement}

Non-fungsional requirement merupakan suatu kebutuhan yang menitikberatkan pada pembatasan solusi yang dimiliki suatu perangkat lunak [11]. Kebutuhan non-fungsional membatasi layanan atau fungsi yang ditawarkan oleh sistem. Batasan tersebut diantaranya usability, portability, reliability, dan supportability.

\section{Fitur Software}

Setelah requirement berhasil dideskripsikan, selanjutnya mendeskripsikan fitur software jejaring kata. Fitur merupakan fungsi khusus yang disediakan oleh sistem. Terdapat dua fitur yang akan disediakan oleh software jejaring kata ini, yaitu fitur input otomatis dan fitur hitung kemiripan kata. 


\section{Desain Software}

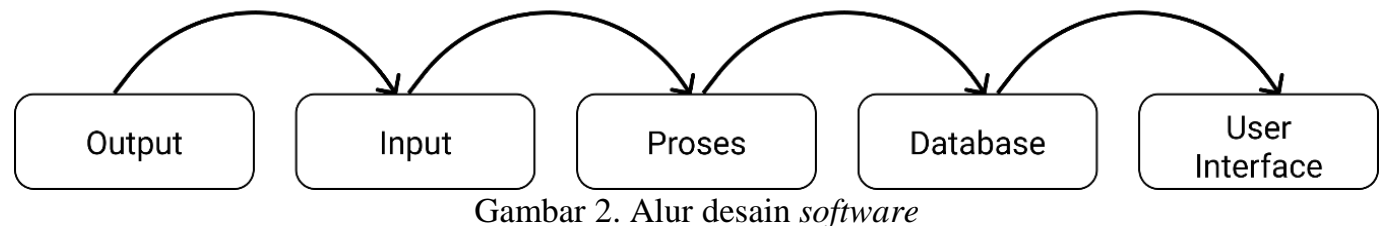

Gambar 2 menunjukkan alur desain suatu sistem perangkat lunak. Alur desain pada penelitian ini terurut mulai dari desain output, input, proses, database, dan user interface.

\section{Desain Output}

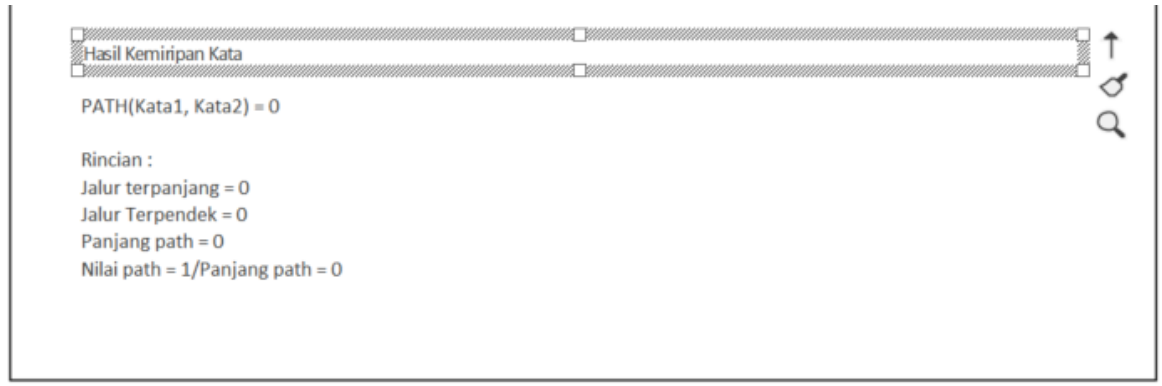

Gambar 3. Desain output

Gambar 3 menunjukkan tampilan desain output yang akan dihasilkan oleh software jejaring kata. Desain output adalah tampilan yang menunjukkan hasil masukkan yang telah dilakukan sebelumnya. Pada penelitian ini, output dari software jejaring kata menghasilkan suatu nilai kemiripan kata Bahasa Indonesia.

\section{Desain Input}

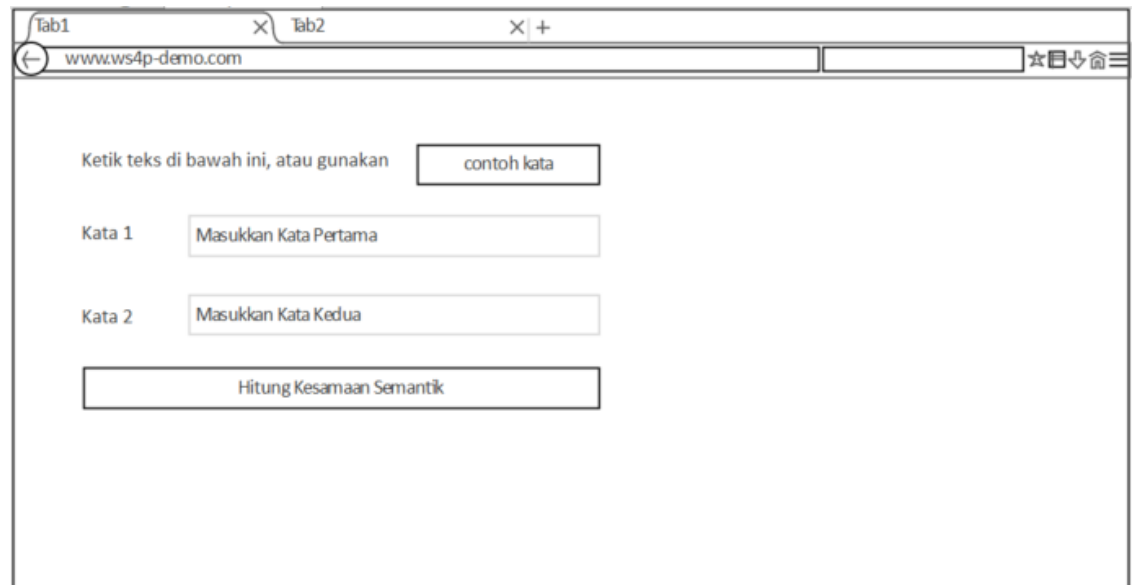

Gambar 4. Desain input

Gambar 4 menunjukkan desain input software jejaring kata. Desain input adalah tampilan yang digunakan untuk memasukkan data ke dalam database. Pada penelitian ini, software jejaring kata menyediakan dua form untuk penginputan kata berbahasa Indonesia. Dua kata yang telah di inputkan nantinya akan dihitung kemiripan katanya.

\section{Desain Proses}




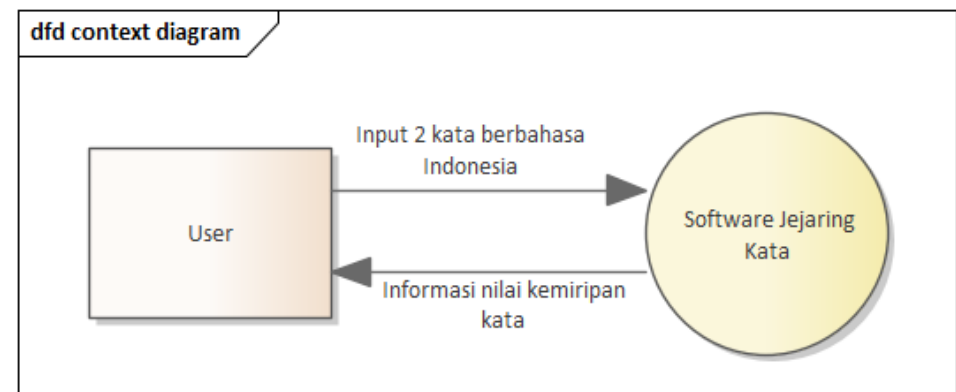

Gambar 5. Diagram Konteks

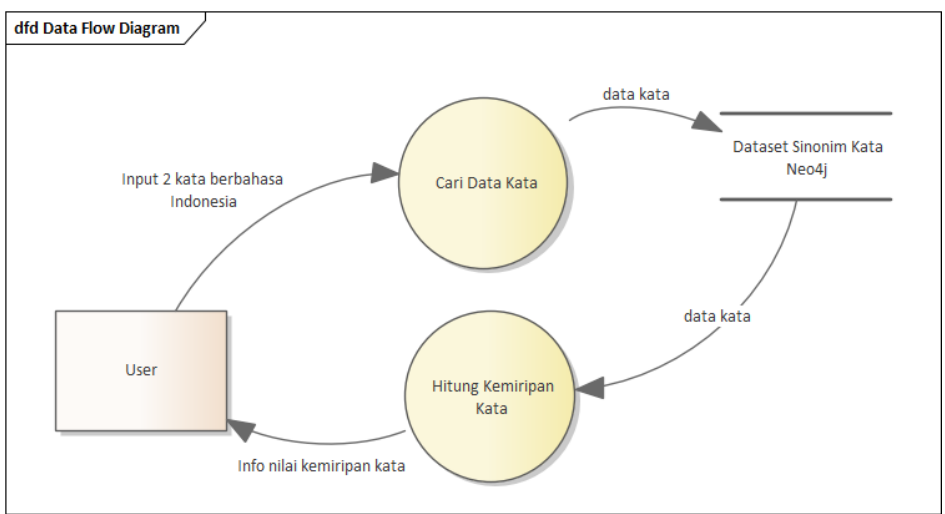

Gambar 6. Data Flow Diagram (DFD)

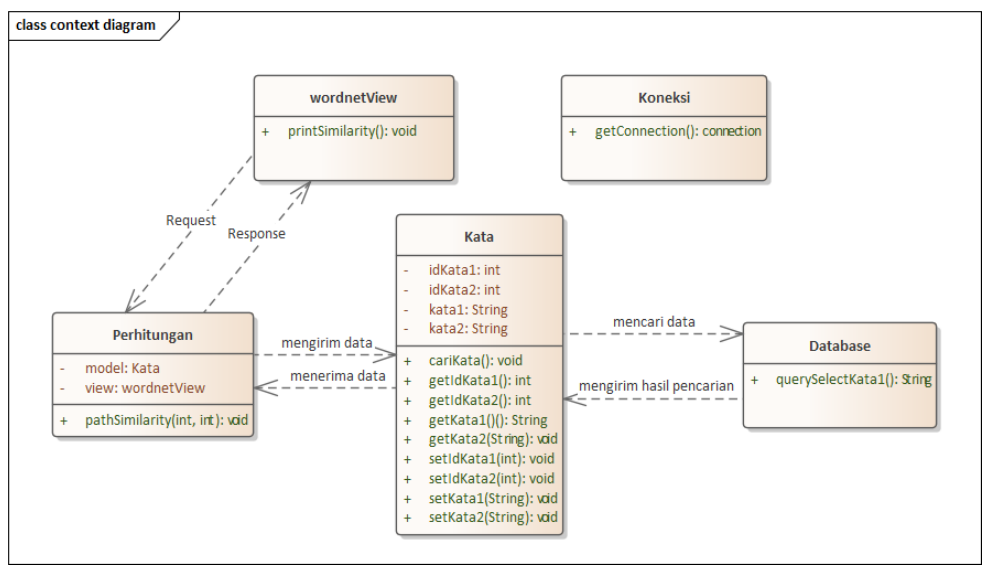

Gambar 7. Class Diagram

Desain proses merupakan tahapan yang dilakukan oleh perangkat lunak untuk mencapai tujuannya. Pada penelitian ini, desain proses pada software jejaring kata dijabarkan dalam tiga diagram. Diagram pertama (Gambar 5) menggambarkan sistem secara garis besar dalam bentuk diagram konteks (DAD). Diagram kedua (Gambar 6) menggambarkan fungsi logika dari sebuah software dalam bentuk Data Flow Diagram (DFD). Diagram ketiga (Gambar 7) menggambarkan set kelas dan objek yang memiliki hubungan timbal balik dalam suatu class diagram [11].

\section{Desain Database}

Desain database software jejaring kata menjelaskan konsep graph yang digunakan. Database manajemen dalam software jejaring kata ini menggunakan Neo4j untuk menyimpan data dalam bentuk graph. Konsep graph yang digunakan dibagi menjadi dua bagian, yakni bagian relasi dan node [12]. 


\section{Bagian Node}

Bagian ini menjelaskan node di dalam graph database Neo4j. Dalam software ini, node mempresentasikan kata kerja dan kata benda yang telah dimasukkan dari sinonimkata.com. Di dalam node terdapat sebuah label sebagai tipe dari node tersebut. Keseluruhan label yang digunakan pada software jejaring kata ditunjukkan pada Tabel 1 .

Tabel 1. Label dalam Graph Database Software Jejaring Kata

\begin{tabular}{|c|l|l|}
\hline Label & \multicolumn{1}{|c|}{ Keterangan } & \multicolumn{1}{|c|}{ Sampel Data Kata } \\
\hline Kt_Kerja & $\begin{array}{l}\text { Label ini merujuk pada dataset kata Bahasa } \\
\text { Indonesia yang tergolong dalam kata kerja. }\end{array}$ & $\begin{array}{l}\text { Membagi, membuat, mengisi, mendata, } \\
\text { aktivasi, merancang. }\end{array}$ \\
\hline Kt_Benda & $\begin{array}{l}\text { Label ini merujuk pada dataset kata Bahasa } \\
\text { Indonesia yang tergolong dalam kata benda. }\end{array}$ & $\begin{array}{l}\text { Setoran, santri, pondok, koperasi, } \\
\text { masyarakat, quran. }\end{array}$ \\
\hline
\end{tabular}

Selain label, node juga mempunyai sebuah properti yang mendeskripsikan keterangan tambahan pada node. Seluruh node pada dataset kata memiliki properti yang sama yaitu name. Properti ini merujuk pada nama dari sebuah node yang diambil dari dataset sinonimkata.com.

\section{Bagian Relasi}

Bagian ini menjelaskan hubungan antar node di dalam graph database Neo4j. Relasi ini mempresentasikan hubungan kata pertama dengan kata lainnya dalam suatu tipe relasi. Dalam dataset yang dibuat, tipe relasi yang digunakan yaitu sinonim. Tipe relasi ini mempresentasikan hubungan kemiripan antar kata dalam graph database Neo4j.

\section{Desain User Interface}

User interface menentukan tampilan perangkat lunak yang akan disajikan kepada pengguna. Desain user interface atau antarmuka pengguna merupakan bagian krusial dari proses desain software. Desain ini mencakup interaksi yang dilakukan pengguna terhadap sistem, sekaligus informasi yang ditampilkan sistem kepada pengguna [12]. Desain user interface perlu memastikan bahwa interaksi antar mesin dan manusia menyajikan pengoperasian yang efisien dan efektif. Informasi utama yang disajikan sistem ini berupa nilai kemiripan kata beserta rincian hasil perhitungan kemiripan kata.

\section{Perhitungan Kemiripan Kata}

Pada bagian ini menjabarkan mengenai implementasi metode semantic similarity untuk menghitung kemiripan kata. Metode perhitungan kemiripan kata pada penelitian ini menggunakan pendekatan path. Metode path dibuat untuk bekerja pada struktur hirarki. Metode ini dihitung melalui persamaan berikut [13] :

$$
\operatorname{Sim}(C 1, C 2)=2 \times \operatorname{Max}(C 1, C 2)-S P
$$

Persamaan (1) adalah persamaan yang digunakan untuk mengakumulasi nilai dari kemiripan kata dengan memanfaatkan pendekatan path. Fungsi Max() merupakan rute maksimum antara node $\mathrm{C} 1$ dan $\mathrm{C} 2$ pada pengelompokkan kata. SP merupakan rute terpendek yang merelasikan $\mathrm{C} 1$ dan $\mathrm{C} 2$. Contoh perhitungan menggunakan path :

Kata 1 : mengisi

Kata 2 : mendata 
Dalam pencarian kata 'mengisi' dan 'mendata' memiliki jalur maksimal 5 dan jalur minimal 2. Perhitungan kemiripan kata tersebut ditunjukkan pada Tabel 2.

Tabel 2. Nilai kemiripan kata

\begin{tabular}{|l|c|}
\hline \multirow{2}{*}{} & \multicolumn{2}{|c|}{ Nilai } \\
\cline { 2 - 3 } Max(C1,C2) & mengisi (C1) \\
\hline SP & 5 \\
\hline Sim(C1,C2) & 2 \\
\hline Path(C1,C2) & $2 \times 5-2=8$ \\
\hline
\end{tabular}

\section{Skenario Eksperimen}

Skenario eksperimen dilakukan untuk menganalisis kesesuaian antara desain perangkat lunak dengan permasalahan. Tujuan yang akan dicapai dari eksperimen ini adalah untuk menjawab persoalan yang ada pada penelitian ini. Berikut adalah skenario eksperimen yang dilakukan: (1) Skenario Pertama adalah enganalisis kesesuaian antara desain, requirement, dan permasalahan yang ada. (2) Skenario Kedua yakni mengukur kemiripan kata menggunakan metode path. Dari skenario eksperimen tersebut, penelitian ini memberikan sebuah kontribusi dalam pengembangan software jejaring kata berbahasa Indonesia menggunakan graph database. Kontribusi yang diberikan yaitu menjelaskan proses perhitungan kemiripan kata pada software jejaring kata menggunakan graph database. Hal itu dikarenakan pada penelitian sebelumnya belum mengimplementasikan proses perhitungan kemiripan kata [14].

\section{Rancangan Pengujian Software (Verifikasi)}

Rancangan pengujian software menjabarkan metode yang digunakan untuk memverifikasi desain perangkat lunak. Dalam perancangan pengujian ini, akan diuji fungsionalitas dari software jejaring kata. Pengujian fungsionalitas software mencakup bagian input kata, dan visualisasi hasil. Berikut skenario perancangan pengujian software yang ditunjukkan pada Tabel 3.

Tabel 3. Skenario rancangan pengujian fungsionalitas software jejaring kata

\begin{tabular}{|c|l|l|}
\hline \multicolumn{1}{|c|}{ Bagian } & \multicolumn{1}{|c|}{ Cara Pengujian } & \multicolumn{1}{|c|}{ Hasil yang Diharapkan } \\
\hline Input kata & $\begin{array}{l}\text { Memasukkan dua kata berbahasa } \\
\text { Indonesia ke dalam form input } \\
\text { kata. }\end{array}$ & $\begin{array}{l}\text { Software memvalidasi kata yang } \\
\text { dimasukkan. }\end{array}$ \\
\hline Visualisasi hasil & $\begin{array}{l}\text { Menekan tombol 'Hitung } \\
\text { Kemiripan kata setelah } \\
\text { memasukkan kata. }\end{array}$ & $\begin{array}{l}\text { Software menampilkan hasil berupa nilai } \\
\text { kemiripan kata menggunakan metode } \\
\text { path. }\end{array}$ \\
\hline
\end{tabular}

Sedangkan pemetaan verifikasi kesesuaian rumusan masalah, requirement, dan desain ditunjukkan pada Tabel 4.

Tabel 4. Verifikasi rumusan masalah, requirement, dan desain

\begin{tabular}{|c|c|c|}
\hline Rumusan Masalah & Requirement & Desain \\
\hline \multirow[t]{2}{*}{$\begin{array}{l}\text { Bagaimana menentukan } \\
\text { tingkat kemiripan antar } \\
\text { kata dalam jejaring kata } \\
\text { berbahasa Indonesia }\end{array}$} & $\begin{array}{l}\text { Menyediakan form untuk } \\
\text { menginputkan dua kata } \\
\text { berbahasa Indonesia untuk } \\
\text { dihitung kemiripan katanya. }\end{array}$ & $\begin{array}{l}\text { Terdapat form input kata yang digunakan } \\
\text { untuk memasukkan dua kata berbahasa } \\
\text { Indonesia. }\end{array}$ \\
\hline & $\begin{array}{l}\text { Software harus dapat melakukan } \\
\text { perhitungan kemiripan kata } \\
\text { berbahasa Indonesia. }\end{array}$ & $\begin{array}{l}\text { Terdapat tombol 'Hitung Kemiripan kata' } \\
\text { untuk mengukur tingkat kemiripan kata } \\
\text { menggunakan metode path. }\end{array}$ \\
\hline
\end{tabular}




\section{HASIL DAN PEMBAHASAN}

\section{Hasil Analisis Requirement}

\section{Fungsional Requirement}

Pada bagian ini telah dihasilkan beberapa kebutuhan fungsional berdasarkan permasalahan yang ada. Kebutuhan fungsional ini nantinya akan dikembangkan menjadi sebuah fitur. Kebutuhan fungsional dari software jejaring kata dijabarkan pada Tabel 5 seperti berikut:

Tabel 5. Fungsional requirement software jejaring kata

\begin{tabular}{|c|l|}
\hline No. & \multicolumn{1}{|c|}{ Kebutuhan Fungsional } \\
\hline $\mathbf{1}$ & $\begin{array}{l}\text { Software harus dapat melakukan perhitungan kemiripan kata berbahasa Indonesia. } \\
\text { Menyediakan form untuk memasukkan dua kata berbahasa Indonesia untuk dihitung kemiripan } \\
\text { katanya. }\end{array}$ \\
\hline $\mathbf{3}$ & Dataset yang digunakan untuk perhitungan kemiripan kata berasal dari sinonimkata.com. \\
\hline $\mathbf{4}$ & Software harus dapat memvisualisasikan hasil perhitungan kemiripan kata. \\
\hline
\end{tabular}

\section{Non-fungsional Requirement}

Pada penelitian ini, non-fungsional requirement dari software jejaring kata dijabarkan pada Tabel 6 seperti berikut:

Tabel 6. Non-fungsional requirement software jejaring kata

\begin{tabular}{|c|l|}
\hline Kategori & \multicolumn{1}{|c|}{ Kebutuhan Non-Fungsional } \\
\hline Usability & $\begin{array}{l}\text { Sistem menyediakan form penginputan kata Bahasa Indonesia untuk menghitung } \\
\text { kemiripan kata. }\end{array}$ \\
\hline Portability & Sistem dibangun dalam sebuah aplikasi web. \\
\hline Reliability & $\begin{array}{l}\text {-Sistem dapat diakses dengan cepat. } \\
\text {-Sistem memproses perhitungan kemiripan kata dengan cepat. }\end{array}$ \\
\hline Supportability & Sistem mendukung penginputan kata berbahasa Indonesia. \\
\hline
\end{tabular}

\section{Fitur Software}

Bagian ini merupakan pengembangan dari kebutuhan yang telah dirumuskan diatas. Terdapat tiga fitur yang disediakan oleh software jejariung kata, yakni input otomatis, input manual, dan hitung kesamaan semantik. Tabel 7 menjabarkan fitur yang disediakan oleh software jejaring kata.

Tabel 7. Fitur software jejaring kata

\begin{tabular}{|c|c|}
\hline Fitur & Kemampuan \\
\hline Input otomatis & Memasukkan kata berbahasa Indonesia secara otomatis dengan menekan \\
tombol "contoh kata".
\end{tabular}

\section{Hasil Desain User Interface}




\section{WS4P Indonesia Demo}

WS4P (Wordnet Similarity for PHP) mengukur kesamaan / keterkaitan semantik antara kata-kata Bahasa Indonesia. Ketik teks di bawah ini, atau gunakan

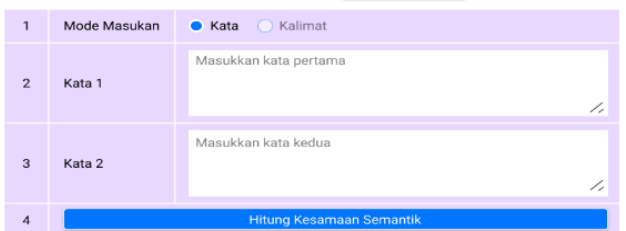

Hasil Kemiripan Kata

$\operatorname{PATH}($ kata1, kata2) $=0$

Rincian :

Jalur terpanjang $=0$

Jalur terpendek $=0$

Nilai path $=1 /$ Panjang_path $=0$

Gambar 8. User interface software jejaring kata

Pada bagian ini, telah di buat desain user interface software jejaring kata. Gambar 8 menunjukkan tampilan desain user interface dari software jejaring kata. Pada tampilan user interface tersebut terdapat bagian input dan output yang dihasilkan. Pada bagian input terdapat dua fitur yang disediakan, yakni input otomatis yang ditandai dengan adanya tombol contoh kata dan fitur manual yang ditandai dengan form input kata. Pada bagian ini disediakan fitur hitung kesamaan semantik yang digunakan untuk mencari nilai kemiripan kata menggunakan metode path. Pada bagian output ditampilkan hasil kemiripan kata berupa nilai path similarity.

\section{Mengukur Kemiripan Kata}

Pengukuran kemiripan kata menggunakan pendekatan path. Sebelum melakukan pengukuran kemiripan kata, dilakukan pencarian kata pada dataset sinonimkata.com yang telah dimasukkan pada Neo4J. Setelah data ditemukan, maka dicari panjang jalur terpanjang dan terpendeknya. Gambar 9 menunjukkan illustrasi panjang jalur kata yang dicari dalam bentuk graf.
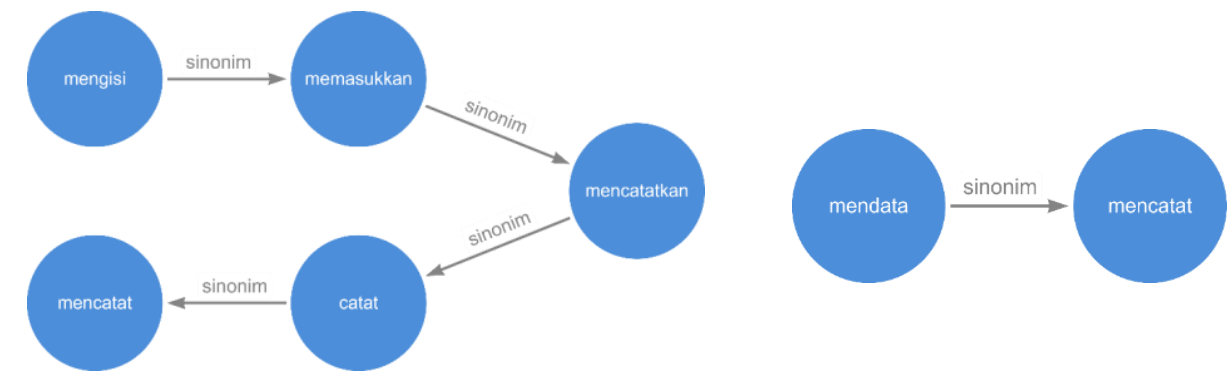

Gambar 9. Graf kata 'mengisi' dan 'mendata'

Pada pencarian kata 'mengisi' dan 'mendata', jalur maksimum bernilai 5 dan jalur minimum bernilai 2 . Selanjutnya dua kata tersebut dihitung kemiripan katanya menggunakan persamaan 1 diatas.

Tabel 8. Perhitungan kemiripan kata

\begin{tabular}{|l|c|c|}
\hline \multirow{2}{*}{ Max(C1,C2) } & Nilai \\
\cline { 2 - 4 } & Mengisi (C1) & Mendata (C2) \\
\hline SP & \multicolumn{2}{|c|}{5} \\
\hline
\end{tabular}




\begin{tabular}{|l|c|}
\hline Sim(C1,C2) & $2 \times 5-2=8$ \\
\hline Path(C1,C2) & $1 / 8=0.125$ \\
\hline
\end{tabular}

Setelah nilai kemiripan kata dihasilkan pada Tabel 8, maka akan ditampilkan pada output software seperti pada Gambar 11. Tampilan output yang dihasilkan berupa nilai path similarity dari kata yang telah dimasukkan.

\section{Hasil Eksperimen (Hasil Analisis)}

Data hasil eksperimen software jejaring kata menunjukkan status kesesuaian dari beberapa kasus yang diuji. Data ini didapatkan berdasarkan rancangan pengujian fungsional (verifikasi) dari perangkat lunak dan pengukuran kemiripan kata. Berikut visualisasi hasil eksperimen software jejaring kata :

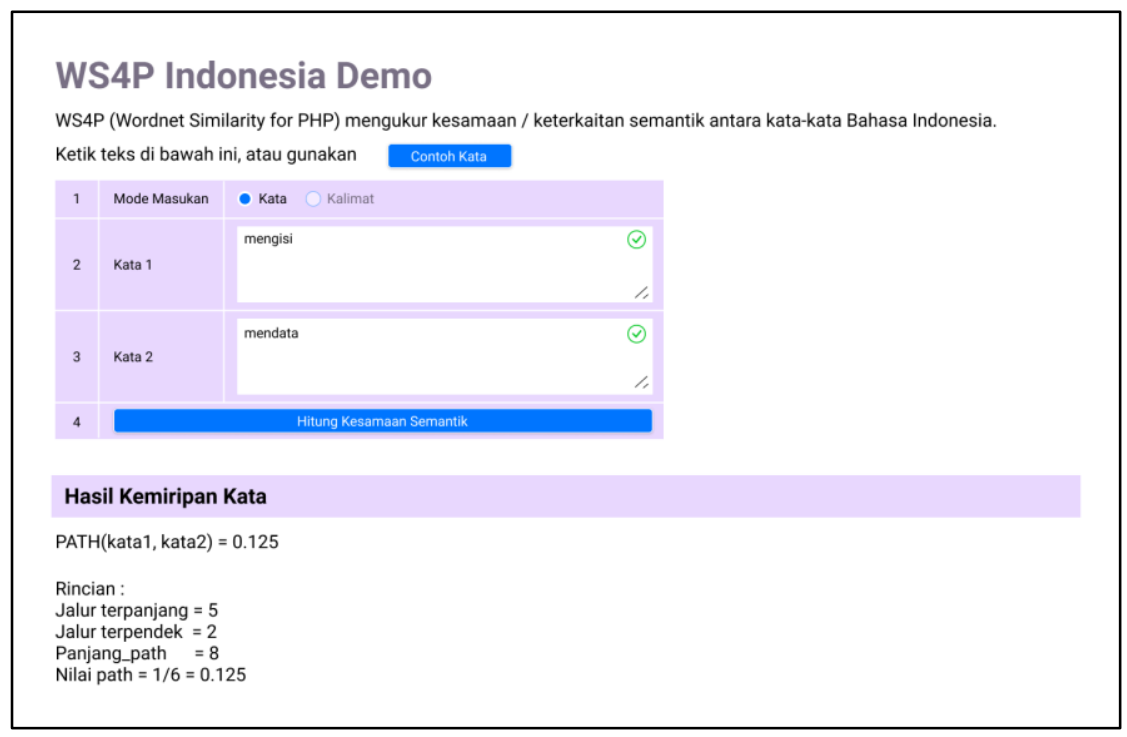

Gambar 11. Visualisasi hasil eksperimen software jejaring kata

Gambar 11 menunjukkan visualisasi hasil eksperimen sebagai bukti kesesuaian antara permasalahan terhadap desain sistem yang dibuat. Visualisasi hasil tersebut menunjukkan kesesuaian terhadap fungsionalitas software jejaring kata.

Tabel 9. Hasil eksperimen

\begin{tabular}{|c|l|l|c|}
\hline \multicolumn{1}{|c|}{ Bagian } & \multicolumn{1}{|c|}{ Eksperimen } & \multicolumn{1}{c|}{ Hasil } & Status \\
\hline Input kata & $\begin{array}{l}\text { Memasukkan dua kata } \\
\text { berbahasa Indonesia ke dalam } \\
\text { form input kata. }\end{array}$ & $\begin{array}{l}\text { Software berhasil memvalidasi } \\
\text { kata yang dimasukkan. }\end{array}$ & Sesuai \\
\hline Visualisasi hasil & $\begin{array}{l}\text { Menekan tombol 'Hitung } \\
\text { Kemiripan kata' setelah } \\
\text { memasukkan kata. }\end{array}$ & $\begin{array}{l}\text { Software berhasil menampilkan } \\
\text { hasil berupa nilai kemiripan kata } \\
\text { menggunakan metode path. Nilai } \\
\text { kemiripan kata ditunjukkan pada } \\
\text { Tabel 8. }\end{array}$ & Sesuai \\
\hline
\end{tabular}

Tabel 9 menunjukkan hasil fungsionalitas bahwa seluruh eksperimen berhasil dilakukan dan sesuai dengan harapan. 
Penjelasan hasil eksperimen software jejaring kata berfokus pada seluruh bagian yang diuji. Hal ini bertujuan untuk memberikan keterangan tambahan terkait kesesuaian antara desain perangkat lunak terhadap permasalahan. Hasil dari pengujian pada seluruh bagian ditunjukkan pada Tabel 9. Eksperimen pengukuran kemiripan kata menggunakan metode path telah ditunjukkan pada Tabel 8.

Tabel 10. Hasil Verifikasi rumusan masalah, requirement, dan desain

\begin{tabular}{|c|c|c|c|}
\hline Rumusan Masalah & Requirement & Desain & Status \\
\hline \multirow[t]{2}{*}{$\begin{array}{l}\text { Bagaimana } \\
\text { menentukan tingkat } \\
\text { kemiripan antar kata } \\
\text { dalam jejaring kata } \\
\text { berbahasa Indonesia }\end{array}$} & $\begin{array}{l}\text { Menyediakan form } r \text { untuk } \\
\text { menginputkan dua kata } \\
\text { Indonesia untuk dihitung } \\
\text { katanya. }\end{array}$ & $\begin{array}{lr}\text { Terdapat form input kata } \\
\text { yang digunakan untuk } \\
\text { memasukkan dua kata } \\
\text { berbahasa Indonesia. }\end{array}$ & Sesuai \\
\hline & $\begin{array}{l}\text { Software harus dapat melakukan } \\
\text { perhitungan kemiripan kata berbahasa } \\
\text { Indonesia. }\end{array}$ & $\begin{array}{l}\text { Terdapat tombol 'Hitung } \\
\text { Kemiripan kata' untuk } \\
\text { mengukur tingkat kemiripan } \\
\text { kata menggunakan metode } \\
\text { path. }\end{array}$ & Sesuai \\
\hline
\end{tabular}

Tabel 10 menunjukkan hasil verifikasi rumusan masalah, requirement, dan desain software jejaring kata. Hasil verifikasi tersebut diambil berdasarkan hasil eksperimen pada Tabel 9 dan visualisasi hasil eksperimen pada Gambar 11. Berdasarkan tabel tersebut dapat dievaluasi bahwa semua requirement yang dirumuskan sesuai dengan desain software yang dibuat dan mampu menyelesaikan permasalahan.

\section{KESIMPULAN}

Berdasarkan hasil penelitian, penggunaan graph database pada software jejaring kata untuk menghitung kemiripan antar kata dapat dilakukan dengan menggunakan metode path. Metode path yang diimplementasikan diambil dari panjang jarak antar node pada graph database Neo4j. Node tersebut mempresentasikan kata berbahasa indonesia yang dicari. Hasil perhitungan kemiripan kata divisualisasikan dalam bentuk desain software jejaring kata. Pada analisis dan desain software jejaring kata diperlukan tahapan terstruktur. Tahapan yang dilakukan berupa analisis requirement, desain software, dan verifikasi. Pada tahap analisis requirement perlu dirumuskan kebutuhan fungsional dan non-fungsional software jejaring kata. Pada tahap desain software diperlukan beberapa tahapan seperti desain output, input, proses, database, dan user interface. Pada tahap verifikasi digunakan untuk memvalidasi antara permasalahan, requirement, dan desain. Dari tahapan tersebut didapatkan hasil bahwa desain software jejaring kata yang telah dikembangkan sudah sesuai dengan requirement dan mampu menyelesaikan permasalahan.

\section{REFERENSI}

[1] T. Wei, Y. Lu, H. Chang, Q. Zhou, and X. Bao, "A semantic approach for text clustering using WordNet and lexical chains," Expert Syst. Appl., vol. 42, no. 4, pp. 2264-2275, 2015, doi: 10.1016/j.eswa.2014.10.023.

[2] Y. Caterina, M. A. Yaqin, and S. Zaman, "Pengukuran Kemiripan Makna Kalimat Dalam Bahasa Indonesia Menggunakan Metode Path,” Fountain Informatics J., vol. 2, no. 1, pp. 1-6, 2016.

[3] E. G. Caldarola, A. Picariello, and A. M. Rinaldi, "Big graph-based data visualization experiences: The WordNet case study," IC3K 2015 - Proc. 7th Int. Jt. Conf. Knowl. Discov. Knowl. Eng. Knowl. 
Manag., vol. 1, no. November, pp. 104-115, 2015, doi: 10.5220/0005632201040115.

[4] M. Syauqi Hanif Ardani, M. A. Yaqin, and M. H. Suhartono, "Implementasi Graph Database Untuk Menentukan Rute Perjalanan Transportasi Umum," 2019.

[5] W. Wahyudi and F. Akbar, "Ekstraksi Basis Pengetahuan Ke Dalam Basisdata Graf Menggunakan Graf Property," J. Nas. Teknol. dan Sist. Inf., vol. 5, no. 1, pp. 41-48, 2019, doi: 10.25077/teknosi.v5i1.2019.41-48.

[6] W. Li, T. Wang, J. Cao, and C. Tao, A Visual Semantic Relations Detecting Method Based on Wordnet, vol. 294 LNCIST. 2019.

[7] M. A. Yaqin and G. U. Abriani, “Analisis implementasi Metode Semantic Similarity untuk Pengukuran Kemiripan Makna antar Kalimat,” J. Comput. Sci. Appl. Informatics, vol. 1, no. 2, p. 15, 2019.

[8] D. Zamzami, D. Puspitasari, J. T. Informasi, P. Studi, T. Informatika, and P. N. Malang, "Aplikasi Wordnet Indonesia Berdasarkan Kamus Thesaurus Bahasa Indonesia Menggunakan."

[9] H. Hendrik and A. B. Cahyono, "Model WordNet Bahasa Indonesia berbasis Linked Data," J. Nas. Tek. Elektro dan Teknol. Inf., vol. 6, no. 1, pp. 8-14, 2017, doi: 10.22146/jnteti.v6i1.288.

[10] H. Larasati and S. Masripah, "Analisa Dan Perancangan Sistem Informasi Pembelian GRC Dengan Metode Waterfall,” J. Pilar Nusa Mandiri, vol. 13, no. 2, pp. 193-198, 2017.

[11] "Pierre Bourque, Richard E. Fairley - Guide to the Software Engineering Body of Knowledge (SWEBOK(r))_Version 3.0-IEEE Computer Society Press (2014).pdf." .

[12] H. P. Ludyanto, Rancang Bangun Aplikasi User Dependency Tool untuk Database MS SQL Server Berbasis Graph Neo4j. 2018.

[13] T. Slimani, "Description and Evaluation of Semantic Similarity Measures Approaches," Int. J. Comput. Appl., vol. 80, no. 10, pp. 25-33, 2013, doi: 10.5120/13897-1851.

[14] S. M. Pamungkas, M. A. Yaqin, K. Z. Matondang, A. N. Anggraini, and A. C. Fauzan, "Analisis dan Perancangan Software WordNet Bahasa Indonesia dengan Graph Database," Ilk. J. Comput. Sci. Appl. Informatics, vol. 2, no. 2, pp. 198-209, 2020, doi: 10.28926/ilkomnika.v2i2.52. 